\title{
1.3. PUBLIC SERVICES IN LOCAL GOVERNMENTS WITH THE EXAMPLE OF THE CITY OF CZESTOCHOWA
}

\begin{abstract}
Summary
This study discusses the problems of management of public services in local governments provided by budgetary entities and commercial law companies. Based on the author's own experiences, the analysis focused on the services in terms of housing and public transportation. The opportunities for the use of the systems of quality management, environmental management and work safety in the area of services managed by local government of the city of Czestochowa in Poland were also emphasized. The analysis of owner supervision of the local government over municipal companies was also carried out in the context of the most recent results of control in local governments.
\end{abstract}

Keywords: local government, organization and management, municipal management, management systems

\section{Introduction}

Implementation of commonly available public services and continuous improvement in their quality is the most important mission and essence of activities in local governments. Meeting collective needs of the local government community belongs to internal tasks of gminas (gminas are principal units of territorial division in Poland), and, in order to perform them, gminas are allowed to establish organizational entities, especially in the form of budgetary entities, budgetary institutions and commercial law companies (limited liability companies, joint stock companies, limited partnerships and partnerships limited by shares), conclude contracts with other entities, also together with other local government entities.

Gminas are allowed to establish commercial law companies outside the area of public utility and join these companies only if the needs of the local community are not met in the local market and the unemployment present in its area significantly affects the standard of living of its inhabitants as well as when disposal of the municipal property that might represent non-financial contribution of gmina to the company or managing this property in another way causes a substantial loss for the gmina.

The function of general meeting of shareholders in sole shareholder companies owned by local government entities are performed by executive bodies of these entities. The companies with shares owned by local government entities have supervising boards.

The basic characteristic of public services is responsibility of public administration for organization of services in a manner that ensures its continuity and stability. This 
Wrona, T.

means that service recipients can be certain about constant meeting of their collective needs, regardless of the economic conditions (Miszczuk, Miszczuk and Żuk, 2007).

Common availability and improved quality result from efficient management of services by public administration entities that care for ensuring conditions for effective performance of these services based on the standards and the specific market of service providers (eds Zawicki, Mazur and Bober, 2004).

Public services concern a broad range of categories as shown in Table 1.

Table 1: Classification of public services

\begin{tabular}{|c|c|}
\hline $\begin{array}{l}\text { Groups of public } \\
\text { services }\end{array}$ & Categories of public services \\
\hline \multirow{4}{*}{$\begin{array}{l}\text { Administrative } \\
\text { services }\end{array}$} & $\begin{array}{l}\text { Issuing documents at the request of a customer, excluding } \\
\text { administrative decisions, permissions and concessions }\end{array}$ \\
\hline & $\begin{array}{l}\text { Introduction to the register (database) of the data obtained } \\
\text { directly from customers }\end{array}$ \\
\hline & $\begin{array}{l}\text { Issuing permissions and decisions as defined by the } \\
\text { Administrative Procedure Code }\end{array}$ \\
\hline & $\begin{array}{l}\text { Issuing permissions and concessions connected with business } \\
\text { activity regulated by the state }\end{array}$ \\
\hline \multirow{7}{*}{ Social services } & Health care \\
\hline & Education \\
\hline & Culture \\
\hline & Physical culture and recreation \\
\hline & Social assistance and care \\
\hline & Housing \\
\hline & Public security \\
\hline \multirow{6}{*}{ Technical services } & Transport: services and infrastructure \\
\hline & Water management: water supply and wastewater piping \\
\hline & Waste management and maintaining order and cleanliness \\
\hline & Cemeteries \\
\hline & Energy supply (power supply, gas supply, heat supply) \\
\hline & Public greenery \\
\hline
\end{tabular}

Source: (Zawicki, Mazur and Bober, 2004).

The following premises for the choice of individual forms of business activities can be determined:

- budgetary institutions for the entities with relatively small scope of activities and for non-profit activities that are characterized by high social sensitivity to the level and quality of services provided,

- commercial law companies for the entities that provide paid services for relatively greater range of activities, those which require the involvement of the capital for new investments and those with modernization and restructuring character,

- civil law contracts for provision of services allow local government entities to give up direct activity in the market of municipal services through publicprivate partnership (ed. Zalewski, 2007). 
A key problem in the field of providing public services by local governments is their ability to make analyses of unit costs and determine quality parameters that are related to these costs (Borowiec, 2007).

Quality of performance of public services can be determined through evaluation of their efficiency, effectiveness and availability using the measurements of the indices that correspond to the subject of services (Wańkowicz, 2004).

\section{Public services: management and outcomes with the example of local government of the city of Czestochowa, Poland}

Assuming that strategies and programs are the basic instrument of control of local development and performance of public services, the local government in Czestochowa adopted strategy of city development, a long-term investment plan, land use study, 23 sectoral operating programmes (e.g. programmes for environmental protection, waste management, revitalization, public transportation, housing, informatization, supply of electricity, heat and gas etc.).

Public services are provided by the entities organized in various forms as: budgetary entities (City Hall, schools, kindergartens, nursery schools), budgetary institutions (City Road and Transport Authority, City Sports and Leisure Centre - MOSIR, Municipal Cemetery), commercial law companies: limited companies (City Transport Company, Czestochowa City Company - CzPK, Housing Management Department Social Housing Association), joint stock companies (Wastewater Treatement Plant OŚ Warta, Regional Development Agency - ARR), cultural institutions (theatre, philharmonic hall, museum, Gaude Mater Culture Promotion Centre), independent health care institutions (Municipal Polyclinic Hospital), gmina associations (Municipal Gmina Association for Water and Sewage Systems, with Czestochowa and nine gminas in the region associated, being the founding body of the Water and Sewerage Company of the Czestochowa Township - PWiK).

The system for quality management ISO 9001 implemented in 2004 in the City Hall and the adopted objectives for activities aimed at quality management had significant effect on Czestochowa local government institutions (half a year before, the ISO 9001 was obtained by PWiK as first). This certificate was also obtained by: MOSiR (2005), CzPK (2006), Municipal Cemetery (2006), City Road Authority (2006), ZGM TBS (2008), ARR (2006) (Wrona 2011).

Three entities implemented integrated management systems:

- PWiK obtained in 2004 the certificate of Integrated Quality Management System: Environment, after implementation of standards PN-EN ISO 9002:2001 and PN-EN ISO 14001:2005.

- CzPK obtained in 2006 the certificate of Integrated Quality Management System: Environment - Safety, after implementation of standards PN-EN ISO 9001:2001, PN-EN ISO 14001:2005 and PN-N-18001:2004,

- Oś Warta obtained in 2009 the certificate of Integrated Quality Management System: Environment - Safety, after implementation of standards PN-EN ISO 9001:2001, PN-EN ISO 14001:2005 and PN-N 18001:2004 (Wrona 2013). 
Wrona, T.

The most important investments implemented in the area of activities of the above entities was programme for modernization of water and wastewater management including modernization of the wastewater treatment plant, building the water treatment facility, $70 \mathrm{~km}$ of sewerage system and rain collector and building of the Waste Management Plant.

\section{Management of housing resources}

The instruments used by gmina authorities to control development of local housing and municipal resources include strategies for housing development, many-year programs for management of housing resources in the gmina, rents and rental policy and policy for privatization of municipal housing resources (ed. Zalewski, 2007).

The following objectives were defined within the housing policy adopted for the city of Czestochowa:

- preparation of lands for housing for all investors in housing development,

- creation of the housing resources in the gmina to meet the needs of households with lower incomes through various forms of housing (e.g. rental housing) and rationalization of residential policies for current resources.

- containing the decapitalization of housing resources,

- revitalization of current systems of residential housing;

- improving the effectiveness (continuation of the system reform) of management of housing resources in the gmina,

- improving the standard for services provided to tenants,

- creation of the financing system for housing management in the gmina aimed at balancing revenues and expenditures with regard for external sources of finance,

- adaptation of post-industrial and service development in the areas with housing function (Strategy and housing policy 2004).

On behalf of the city of Czestochowa, the functions of management of housing resources are performed by the commercial law company ZGM TBS, with the city of Czestochowa having $100 \%$ shares.

ZGM TBS manages buildings which are municipal property and its activities include in particular:

- maintenance of building, houses and commercial premises with surroundings of these areas in proper technical and aesthetic state,

- subcontracting, through tenders, of renovation, repairs and maintenance of housing resources in the area of lessor responsibility,

- concluding contracts for rental for housing and commercial premises,

- management of buildings that represent the property of natural and legal persons.

The decisions extending the scope of activities of standard authority, concerning e.g. property, investments and management of housing resources are regarded as competencies of gmina (Many-year program for management of housing resources 2004). 
ZGM TBS has concluded the contracts for management of joint property with 334 housing communities that represents the property of the City and persons.

The program which is complementary to housing policy is Municipal Revitalization Program (2005) adopted as a set of many-year activities in the economic, social and land development areas that leads to revival and activation of districts that are being degraded. The directions for their revitalization were adopted with respect to the opportunities for increasing the number of workplaces in service sector, containing social degradation in the areas affected by the consequences of restructuring of the industry and renewed management of post-industrial areas (Wrona, 2014).

Another objective for development of housing in Czestochowa is building flats for rental within the Social Housing Association, oriented at middle-income social group who cannot afford buying the flat in the free market. The effect was building TBS district with 414 flats (following the national-level architectonic contest).

Another outcome of the activities in the area of housing was also the renovation of the whole Dźbów district (37 council buildings) and elimination of low emission and supply of gas to this district and construction of four buildings with social flats.

A problem for management of housing resources is maladjusted structure of owner supervision, with its characteristics being multi-level structure, very high number of participants in the process of management, presence of several types of organizational relationships (double subordination) and the related division of competencies and responsibility (ed. Zalewski, 2007).

\section{Management of public transport}

Transport policy was adopted by defining that the aim of transformations and development of the transport system in Czestochowa is to improve the efficiency and safety of moving people and deliver of goods while limiting the negative effect of transport on the environment. Modernization and development of the transport system should be aimed at stimulation of economic development and spatial order and improvement in the image of the city as a centre with national importance and world religious centre.

The specific goals were:

- ensuring the effectiveness of city functioning with growing level of motorization,

- improvement in quality of public transport,

- improvement in parking conditions,

- limitation of negative effect of transport on the environment, including noise and air pollution,

- improvement in road traffic safety,

- improvement in economic transport effectiveness (Transport Policy, 2004).

Priorities were determined in the integrated plan of transport development and the principles for implementation of transport policy in the City were defined. This aim is closely related with current financial plan and system of management of the City, cooperation with neighbouring gminas and coordination of the activities with related domains (road maintenance, traffic organization). 
Wrona, T.

Current system of public transport is based on the activity of the MPK company, with the city of Czestochowa being the owner with $100 \%$ shares. Urban communication is financed from the revenues on the tickets $(80 \%)$ and surcharges from the city (ca. $20 \%$ ), that represent buyout of concessions defined by the City Council (Integrated Plan, 2009).

The effect of implementation of the plan for public transportation development in Czestochowa was extension of the services of rail transport through e.g. modernization of the tram line traction system $(4.7 \mathrm{~km})$, purchase of new tram rolling stock as well as replacement of the bus fleet (purchase of new 28 buses) and introduction of e-ticket and IT management system.

According to the plan, the public transport system was also reorganized through separation of the function of public transport organizer from the function of carrier (previously it was MPK that determined the scope, range and standard of services, performing the role of contractor and supervisor of these services).

\section{Conclusions}

Management of public services in local governments should be based on thoroughly prepared strategies and plans with regard for the objectives and analytical studies (both internal and external), evaluation of the effectiveness of activities through confrontation of the aims planned with the aims achieved and quality expected with the quality achieved and on the analysis of unit costs of services.

There are more and more areas in the municipal management where business approach should be used, including risk assessment, profit analysis, financial engineering, which determines the rationality and effectiveness of the specific investment activity. However, this involves important problems due to the deficit of ability to cooperate at all the levels of public management and lack of knowledge and experience in the field of business approach among the most of the political leaders (also in local governments) (Kulesza, 2012).

The Minister of State Treasury in 2007-2013 disposed (free of charge), to the local government entities, stocks and shares in 88 companies, including 74 sole shareholder companies of the State Treasury. The audit revealed that this had a positive effect on the effectiveness of performance of tasks, which are essential for local communities and improved the effectiveness of supervision over these companies. One effect of municipalization was also improvement in financial standing of the companies involved. Municipalization of companies allowed for more effective and more economical performance of internal activities of local governments and more effective management of the property owned by these companies (Information P/13/056, 2014). Furthermore, in Łódź Voivodeship (Information P/13/1602014), municipal companies satisfied collective needs of the local government communities but they were additionally active outside the area of public utility and did not demonstrate sufficient diligence in terms of economic and financial results and effectiveness of operation. Municipal companies had difficulties with adjustment to changing market conditions. The supervision over municipal companies by gmina (city) authorities had primarily passive character and focused on formal activities i.e. appointing and dismissal of the 
members of company authorities and approval of annual reports on company activities. The supervision was carried out in an incompetent manner in many areas.

No transparent principles for supervision were developed in local government entities, including the method to carry out technical supervision and economic and financial supervision with respect to the companies and the principles of cooperation with authorities in the companies combined with the goals in the economic and technical areas. This resulted in delayed measures taken towards municipal companies which obtained negative financial results.

It is necessary for local governments to take measures to organize the area of municipal companies, including:

- determination of the principles (standardization) for performance of owner supervision with regard to the companies with participation of the local government, including effective monitoring and competent assessment of the activities of municipal companies,

- determination of ownership policy with respect to the companies supervised,

- starting initiatives aimed at privatization of the companies that are active outside the area of public utility.

Increasing the efficiency of management and effectiveness of supervision over companies is possible through ensuring transparency of selection of properly prepared people for members of supervisory councils, carried out within open procedure.

Available financial data point to a little important aspect of cooperation between local government entities during performance of municipal tasks (ed. Hausner, 2013). Less than $1 \%$ of overall revenues of local governments is transferred based on the agreements (concerning mainly transport). Agreements with gminas have become a source of finance for road investments in many powiats (powiats are principal units of territorial division in Poland of the second level). Cooperation with local government entities during performance of public tasks in commercial law companies is often necessary for performance of the tasks in terms of public transportation, water and sewerage management and waste management. Legal regulations for supervision of such activities are also necessary. Current owner supervision is performed only through the personal relation i.e. participation of the members of supervisory boards in these companies. Local government members of supervisory board should be related with the instructions of the proper decision-making body. An analogous solution should be implemented with respect to each local government entity that acts separately with respect to the local government. Wherever an entity does not have the supervisory council, the instruction should be addressed to the manager or board in the entity.

\section{References}

1. Borowiec, L. (2007): Controlling w realizacji usług publicznych gminy, Wolters Kluwer, Kraków, p. 107.

2. Hausner, J. (ed.) (2013): Narastające dysfunkcje, zasadnicze dylematy, konieczne działania. Raport o stanie samorządności terytorialnej w Polsce, MSAP, Kraków, pp. 57-58, 100. 
3. Information about the results of the audit: municipalization of the companies of the State Treasury, KGP-4101-03-00/2013, No. 133/2014/P/13/056/KGP, Supreme Audit Office, Warsaw 2014

4. Information about the results of the audit: functioning of municipal companies in Łódź Voivodeship, LLO-4101-013-00/2013, No. 162/2014/P/13/160/LLO, Supreme Audit Office, Warsaw 2014.

5. Kulesza, M (2012): Gospodarka komunalna - podstawy i mechanizmy prawne, Samorząd Terytorialny, 7/8, pp. 7-24.

6. Municipal Revitalization Program for Czestochowa, appendix for the Czestochowa City Council Resolution No. 667/XLV/2005 as of May 23, 2005.

7. Miszczuk, A.; Miszczuk, M. and Żuk, K. (2007): Gospodarka samorządu terytorialnego, WNT Warsaw, pp. 140-141.

8. Transport Policy for the City of Czestochowa, appendix for the Czestochowa City Council Resolution No. 449/XXXIII/2004 as of July 5, 2004.

9. Strategy and housing policy for the Gmina of the City of Czestochowa, appendix for the Czestochowa City Council Resolution No. 507/XXXVII/2004 as of November 26, 2004.

10. Wańkowicz, W. (2004): Wskaźniki realizacji usług publicznych, Program Rozwoju Instytucjonalnego, Małopolska Szkoła Administracji Publicznej Akademii Ekonomicznej w Krakowie, Kraków, pp. 2-8.

11. Many-year program for management of housing resources for the Gmina of the City of Czestochowa for 2005-2010, appendix for the Czestochowa City Council Resolution No. 508/XXXVII/2004 as of November 26, 2004.

12. Wrona, T. (2011): Effect of Human Capital on Professionalization of Self-Government Institutions, (in:) The Role of Human Capital In Knowledge Based Management, monograph (eds Bylok, F., Cichobłaziński, L.), Wyd. Politechniki Częstochowskiej, Czestochowa, pp. 188-202.

13. Wrona, T. (2013): Zintegrowane systemy zarządzania w częstochowskim samorządzie, (Bezpieczeństwo systemu: Człowiek - Obiekt techniczny - Otoczenie. Zarządcze i środowiskowe aspekty bezpieczeństwa, monograph, scientific eds: Salamon, Sz,; Tabor, J, T.1, pp. 58-67.

14. Wrona, T. (2014): Revitalization of Cities: Social Aspect, (in:) Management and Managers Facing Challenges of the 21st Century. Theoretical Background and Practical Applications, monograph (eds Bylok, F.; Ubreziova, I. and Cichobłaziński, L.) Szent Istvan Egyetemi Kiado Nonprofit Kft., Gödöllo, pp. 371-380.

15. Zalewski, A. (ed.) (2007): Nowe zarządzanie publiczne w polskim samorządzie, Oficyna Wydawnicza SGH, pp. 230, 268,330.

16. Zawicki, M.; Mazur, S. and Bober, J. (eds) (2004): Program Rozwoju Instytucjonalnego, Zarządzanie w samorządzie terytorialnym. Najlepsze praktyki., Małopolska Szkoła Administracji Publicznej Akademii Ekonomicznej w Krakowie, Ministerstwo Spraw Wewnętrznych i Administracji, Kraków, p. 16.

17. Integrated plan for development of public transport for the City of Czestochowa for 20092015, appendix for the Czestochowa City Council Resolution No. 496/XLIV/2009 as of June 29, 2009. 